\title{
KAJIAN TEORITIS: ANALISIS JARINGAN KOMUNIKASI INTERPERSONAL
}

\author{
Asri Sulistiawati \\ Departemen Sains Komunikasi dan Pengembangan Masyarakat \\ Fakultas Ekologi Manusia, Institut Pertanian Bogor \\ Email: asrisulistya@ipb.ac.id
}

\begin{abstract}
Communication network analysis is one of method that can be used to identify the interaction of individuals in the group. This method not only focused on the individual and the social unit itself, but also the quality of the relationship between social units. This study aims to identify part of communication network concept such as interpersonal communication network. This article contains of a number of concepts related to interpersonal communication networks. Furthemore, this article try to give some descriptions about some researchs that concern about interpersonal comunication network. Therefore, this study aims to identify indicators that researchers often use in their research.
\end{abstract}

Keyword: Communication network, interpersonal communication

\section{PENDAHULUAN}

\section{Latar Belakang}

Berdasarkan sejumlah definisi jaringan yang dikemukakan oleh para ahli, secara ringkas jaringan dapat diartikan sebagai gabungan atau kumpulan individu yang membentuk struktur yang terpola. Adapun komunikasi berarti proses pertukaran informasi dari para pelaku komunikasi untuk mencapai tujuan bersama. Apabila dikaitkan antara kedua konsep tersebut, maka jaringan komunikasi dapat diartikan sebagai kumpulan individu yang saling berinteraksi, berbagi pesan dan informasi untuk mencapai tujuan bersama melalui arus komunikasi yang terpola. Selanjutnya, di dalam jaringan ini dapat diidentifikasi karakteristik struktural serta peran atau posisi individu yang menjadi anggota di dalam suatu jaringan.

Rogers dan Kincaid (1981) mengemukakan bahwa salah satu fungsi dari analisis jaringan komunikasi antara lain dapat mengidentifikasi struktur komunikasi dalam suatu jaringan serta mengidentifikasi struktur dalam subsistem yang memengaruhi perilaku dalam sistem. Lebih lanjut, Prell (2012) mengungkapkan bahwa memahami peranan individu dalam jaringan menjadi bagian penting dalam analisis jaringan sosial karena dapat membantu mengidentifikasi individu-individu yang dianggap paling penting di dalam jaringan.

Penelitian jaringan komunikasi bukan merupakan penelitian yang baru. Meski demikian, Analisis Jaringan Sosial (Social Network Analysis/SNA) masih menjadi topik yang menarik dan banyak dikembangkan oleh sejumlah ahli sampai saat ini. Perkembangan penelitian terkait dengan jaringan komunikasi selama ini pada umumnya masih sebatas menghubungkan peran jaringan komunikasi dengan adopsi inovasi, 
sebagaimana yang telah dilakukan oleh Ramirez (2013) tentang pengaruh jaringan sosial petani terhadap adopsi teknologi pertanian. Penelitian yang dilakukan di bagian tenggara Texas ini menunjukkan bahwa cara terbaik untuk meningkatkan adopsi inovasi petani terhadap teknologi irigasi antara lain melalui pemanfaatan jaringan komunikasi. Hasil penelitian serupa juga ditunjukkan oleh para peneliti dari Indonesia diantaranya Cindoswari (2012) dan Rangkuti (2007). Hasil penelitian yang dilakukan oleh Cindoswari (2012) dan Rangkuti (2007) menunjukkan bahwa terdapat hubungan antara Jaringan Komunikasi dengan penerapan suatu inovasi dimana masing-masing inovasi yang dikemukakan oleh kedua peneliti tersebut antara lain inovasi teknologi produksi ubi kayu dan inovasi traktor tangan.

Sejumlah penelitian di atas secara garis besar memberikan gambaran terkait dengan peranan jaringan komunikasi. Namun demikian, perkembangan penelitian jaringan komunikasi selama ini masih berfokus pada peranannya terhadap adopsi inovasi. Mengutip pernyataan Mudiarta (2009) bahwa bisa saja terjadi keragaman tingkat ketersediaan sumber-sumber daya sosial diantara individu, kelompok, atau dalam komunitas tertentu, yang didominasi oleh kontribusi jaringan kerja yang ada. Dengan demikian, peran jaringan kerja atau jaringan sosial yang tumbuh dalam komunitas lokal sangat mungkin memberikan kontribusi yang signifikan dalam mendukung aktivitas ekonomi masyarakatnya.

\section{PEMBAHASAN}

\section{Analisis Jaringan Komunikasi Interpersonal}

Rogers dan Kincaid (1981) mengidentifikasi peranan khusus individu dalam jaringan misalnya sebagai opinion leader, liaisons, bridges, atau isolated. Sejalan dengan hal itu, Waldstrom (2001) menguraikan peranan individu tersebut sebagai struktur komunikasi informal yang tersusun atas dua elemen yakni nodes dan links. Node dapat didefinisikan sebagai unit analisis dan dengan demikian mereka dapat diidentifikasi sebagai individu, diad (dua orang), subkelompok atau bahkan seluruh kelompok. Individu (nodes) dalam jaringan dapat diidentifikasi menurut peranannya seperti yang tergambar dalam gambar berikut ini.

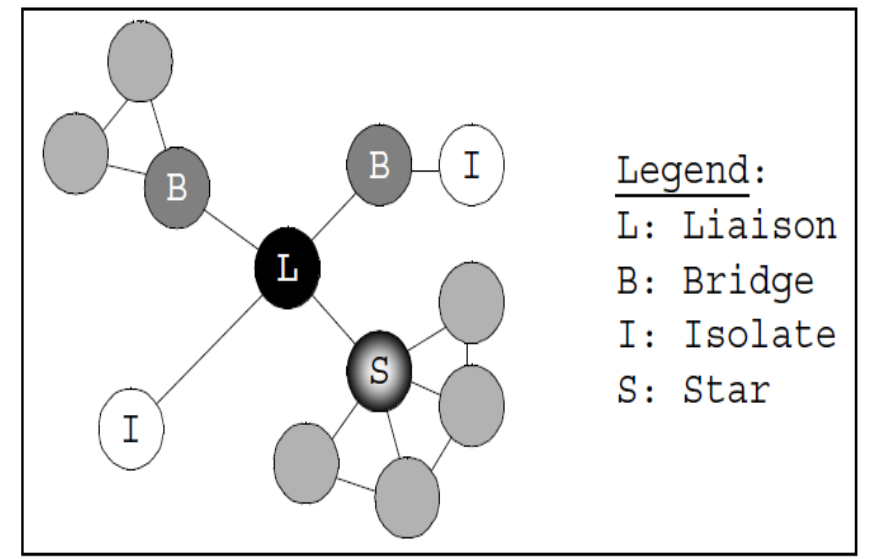

Gambar 2.2 Peranan individu dalam Struktur Komunikasi (Waldstrom, 2001) 
Berikut ini penjelasan mengenai keempat peranan individu di atas:

1. Bridge: anggota kelompok atau klik dalam satu organisasi yang menghubungkan kelompoknya dengan anggota dari kelompok lain sehingga menjembatani dua atau lebih kelompok bersama-sama.

2. Liaisons: sama peranannya dengan bridge tetapi individu itu sendiri bukanlah anggota dari satu kelompok tetapi dia merupakan penghubung di antara satu kelompok dengan kelompok lainnya.

3. Isolate adalah anggota organisasi yang mempunyai kontak dengan orang lain yang minimal. Orang-orang ini cenderung menyendiri di dalam organisasi.

4. Star merupakan individu yang memiliki intensitas komunikasi paling sering (Waldstrom 2001).

Selanjutnya, Mitchell sebagaimana dikutip oleh Scott (2009) mengemukakan bahwa melalui analisis jaringan interpersonal dapat menggambarkan kualitas hubungan antar individu yang saling berinteraksi dalam suatu sistem ataupun dalam kelompok/klik. Adapun tiga indikator utama yang dapat digunakan untuk mengukur jaringan interpersonal antara lain: (1) tingkat resiprositas (reciprocity), (2) intensitas komunikasi, dan (3) durasi. Tingkat resiprositas merupakan hubungan timbal balik antar anggota kelompok yang dilihat dari jumlah hubungan anggota yang saling berbalasan.

Di lain pihak, Prell (2012) menguraikan sejumlah indikator lain yang dapat digunakan dalam menganalisis jaringan komunikasi pada tingkat individu, antara lain: (1) derajat sentralitas (degree centrality), (2) tingkat kedekatan (closeness) dan (3) tingkat kebersamaan (betweeness). Penjelasan mengenai masing-masing indikator tersebut dipaparkan pada paragraf berikut ini.

Derajat sentralitas dikemukakan oleh Scott (2009) berkenaan dengan konsep sosiometri dalam mengidentifikasi individu yang berperan sebagai "star" yakni individu paling populer di dalam sebuah jaringan atau individu yang menempati posisi sentral dan menjadi pusat perhatian. Di lain pihak, Hanneman dan Riddle (2005) mengungkapkan bahwa individu yang menjadi peran sentral menempati posisi yang menguntungkan, karena mereka memiliki banyak hubungan, mereka mungkin memiliki cara-cara alternatif untuk memenuhi kebutuhan, dan karenanya tidak terlalu tergantung pada orang lain.

Adapun Prell (2013) menyatakan bahwa Individu yang memiliki derajat sentralitas paling tinggi dapat diidentifikasi sebagai pemimpin, atau dapat pula pusat dari lingkaran gosip, atau dapat pula sebagai orang pertama yang mendapatkan informasi atau berita. Dengan kata lain, individu yang menjadi peran sentral tidak selalu merupakan pemimpin di dalam kelompok maupun jaringan. Hal ini sejalan dengan hasil temuan Malinick et al. (2013), yang menemukan bahwa pemimpin formal tidak menempati posisi sentral di dalam jaringan, dengan kata lain pemimpin formal tidak berhubungan secara signifikan terhadap derajat sentralitas.

Derajat sentralitas menurut Prell (2013) dapat digunakan sebagai ukuran tingkat keterlibatan atau aktivitas individu di dalam jaringan. Masih di dalam Prell (2013) tertulis bahwa, dalam jaringan komunikasi, individu yang memiliki derajat sentralitas yang tinggi merupakan saluran utama dalam informasi. Individu ini berbicara kepada banyak anggota di dalam jaringan, sehingga individu ini dapat mendengar dan membagi informasi dengan cepat.

Dalam menganalisis derajat sentralitas, Scott (2009) membagi dua konsep sentralitas yakni sentralitas lokal (local centrality) dan sentralitas global (global centrality). Sentralitas lokal merupakan derajat yang menunjukkan seberapa baik individu terhubung dengan individu lainnya dalam lingkungan terdekat. Adapun sentralitas global 
menunjukkan kemampuan yang dimiliki individu dalam menghubungi semua individu dalam sistem.

Selanjutnya, Prell (2013) menguraikan bahwa terdapat dua derajat pengukuran lainnya yang dapat digunakan untuk mengukur sentralitas khususnya untuk analisis jaringan komunikasi yang mempersepsikan arah/aliran informasi sebagai komponen penting, yakni derajat ke dalam (indegree) dan derajat ke luar (outdegree). Derajat sentralitas ke dalam (indegree centrality) merupakan jumlah ikatan (ties) yang diterima individu dari anggota lainnya. Adapun Derajat sentralitas ke luar (outdegree centrality) merupakan jumlah ikatan yang diberikan individu terhadap anggota lainnya dalam jaringan.

Hal lain yang dapat dilakukan dalam menganalisis jaringan komunikasi antara lain melalui pengukuran terhadap derajat/tingkat kedekatan individu dengan individu lainnya (closeness). Tingkat kedekatan ini dilihat dari jarak terdekat yang ditempuh individu dalam berhubungan dengan anggota lainnya. Individu yang memiliki jarak paling pendek terhadap anggota lainnya merupakan individu yang memiliki derajat kedekatan paling tinggi. Adapun Monge dan Contractor (2003) secara sederhana mengemukakan konsep kedekatan (closeness) sebagai tingkat kemampuan individu dalam mengakses informasi secara efisien.

Konsep berikutnya yang dapat digunakan dalam menganalisis jaringan komunikasi pada tingkat individu antara lain tingkat kebersamaan (betweeness). Betweeness ini melihat seberapa sering individu berada diantara dua orang anggota lainnya di dalam sebuah jaringan. Secara khusus, betweenness mengukur berapa banyak individu menempati posisi sebagai geodesic (jalur terpendek) diantara dua anggota lainnya. Di dalam Jaringan komunikasi, betweenness mengukur seberapa besar kontrol yang dimiliki individu dalam membagi informasi (Prell 2013). Adapun Scott (2009) menyebutkan bahwa salah satu fungsi pengukuran betweeness ini yakni dapat mengidentifikasi keberadaan individu yang dapat berperan sebagai broker atau gatekeeper.

Berdasarkan pemaparan sejumlah indikator dalam analisis jaringan interpersonal di atas, dapat dikatakan bahwa terdapat perbedaan penekanan terhadap ketiga konsep di atas sebagaimana dikemukakan oleh Prell (2013). Perbedaan penekanan tersebut antara lain derajat sentralitas yang menekankan pada aktivitas, tingkat kebersamaan menekankan pada potensi kontrol dalam aliran informasi, dan derajat kedekatan menekankan pada individu.

\section{Hasil-hasil Studi Jaringan Komunikasi dan State of The Art}

Penelitian jaringan komunikasi bukan merupakan penelitian yang baru. Meski demikian, Analisis Jaringan Sosial (Social Network Analysis/SNA) masih menjadi topik yang menarik dan banyak dikembangkan oleh sejumlah ahli sampai saat ini. Berikut ini pemaparan hasil penelusuran sejumlah penelitian berkenaan dengan SNA dan atau jaringan komunikasi.

Saleh (2006) yang salah satu tujuan penelitiannya antara lain melihat hubungan karakteristik personal terhadap perilaku komunikasi interpersonal individu dalam jaringan komunikasi peternak sapi potong. Temuan Saleh (2006) menunjukkan adanya hubungan sangat nyata dan berkorelasi positif antara karakteristik personal dengan perilaku komunikasi interpersonal peternak sapi potong mulai dari perilaku menerima, mencari, mengklarifikasi dan menyebarkan informasi. Sejalan dengan itu, Ellyta (2006), Mislini (2007) dan Rangkuti (2007) juga menemukan hal yang sama dalam penelitiannya yang 
menemukan adanya hubungan yang positif antara karakteristik personal dengan jaringan komunikasi.

Sehubungan dengan itu, meski keempat peneliti tersebut menganalisis hal yang sama yakni jaringan komunikasi, namun masing-masing peneliti mencoba mengaitkannya dengan topik yang berbeda. Jika Saleh (2006) mengaitkan jaringan komunikasi dengan perilaku komunikasi dalam penyebaran informasi, lain halnya dengan Ellyta (2006) yang mencoba mengaitkan hubungan jaringan komunikasi terhadap pemasaran. Adapun Mislini (2007) melihat jaringan komunikasi sebagai variabel independent yang memengaruhi variabel lainnya, yakni dinamika kelompok. Hal lainnya dikaji oleh Rangkuti (2007) yang menghubungkan jaringan komunikasi dengan adopsi inovasi. Di lain pihak, hal berbeda ditunjukkan pula oleh Agustina (2007) yang mengkaji Jaringan Komunikasi dan Peran Perempuan dalam Mempertahankan Budaya Rudat, dimana dari hasil penelitiannya ditemukan bahwa terdapat hubungan antara jaringan komunikasi dengan peran perempuan dalam proses penyebaran dan pelaksanaan budaya Rudat di Desa Negeri Katon.

Selanjutnya penelitian lain terkait jaringan komunikasi secara lebih spesifik telah dikaji Cindoswari (2013) dan Bulkis (2013) yang mengkaji mengenai sentralitas lokal dan sentralitas global. Pada penelitian Cindoswari (2013) menunjukkan adanya hubungan antara karakteristik individu dengan derajat sentralitas. Temuan lainnya menunjukkan bahwa terdapat hubungan yang positif antara derajat sentralitas pada jaringan komunikasi dengan penerapan teknologi produksi. Sementara itu hasil temuan Bulkis (2013) menunjukkan adanya hubungan antara sentralitas lokal dengan pembentukan kognisi dan afeksi, namun tidak ditemukan adanya hubungan antara sentralitas global dengan pembentukkan kognisi dan afeksi.

Di sisi lain, hasil penelitian Demiryurek (2010) menunjukkan adanya perbedaan dampak jaringan komunikasi. Hasil temuannya menunjukkan bahwa organisasi yang memiliki jaringan komunikasi yang kuat berimplikasi pada semakin terbukanya akses informasi. Sementara itu, jaringan komunikasi yang lemah ditunjukkan dengan lemahnya interaksi diantara anggota sehingga berimplikasi kepada lemahnya kerjasama antar stakeholder.

Penelitian selanjutnya, yang dilakukan oleh Ramirez (2013) dengan hasil temuan yang menunjukkan bahwa petani yang memiliki derajat sentralitas paling tinggi merupakan saluran komunikasi utama. Adapun petani yang termasuk ke dalam kategori ini merupakan petani pemilik yang memiliki peran sentral dalam berbagi informasi dan memiliki pengaruh terhadap petani lainnya. Sementara itu, faktor penentu klasik seperti umur, pendidikan, dan ukuran lahan tidak memengaruhi aliran informasi dan adopsi teknologi. Faktor utama yang memengaruhi adopsi teknologi konservasi air antara lain adalah tingkat partisipasi petani dalam suatu kelompok atau organisasi.

Penelitian mengenai jaringan komunikasi dalam kaitannya dengan adopsi inovasi lainnya, dilakukan pula oleh Ramirez et al. (2014). Hasil temuannya menunjukkan bahwa jaringan sosial berpengaruh terhadap adopsi teknologi tungku non tradisional di Honduras Barat.

Di lain pihak, van den Berg et al. (2013) meneliti jaringan komunikasi pada aspek yang berbeda yakni jaringan komunikasi yang dikaitkan dengan aktivitas sosial, penggunaan teknologi komunikasi dan pola perjalanan. Hasil temuannya menunjukkan bahwa terdapat pengaruh yang signifikan antara perilaku perjalanan sosial (social travel behavior) dengan ukuran jaringan sosial dan penggunaan teknologi komunikasi. Selain itu, temuan lainnya menunjukkan bahwa ukuran jaringan sosial berpengaruh positif terhadap jumlah perjalanan sosial dengan modus yang berbeda serta jarak perjalanan sosial yang berbeda. 
Berdasarkan hasil penelusuran sejumlah penelitian di atas, khususnya penelitian yang dilakukan oleh Saleh (2006), Ellyta (2006), Mislini (2007) dan Rangkuti (2007), dapat dikatakan bahwa variabel karakteristik sumber daya individu merupakan variabel penting yang dapat mempengaruhi jaringan komunikasi. Hal ini sejalan pula dengan Demiryurek (2007) dan Ramirez (2013) dimana masing-masing menyebutnya sebagai variabel sosio-ekonomik dan faktor penentu klasik. Sehubungan dengan itu, maka variabel karakteristik individu dapat menjadi bahan acuan pada penelitian ini sebagai variabel yang turut mempengaruhi jaringan komunikasi. Terlebih pada penelitian ini secara khusus mengkaji analisis jaringan komunikasi pada tingkat individu.

\section{PENUTUP}

Berdasarkan hasi penelusuran sejumlah studi terdahulu berkenaan dengan Jaringan Komunikasi, dapat dikatakan bahwa karakteristik sumberdaya individu menjadi salah satu variabel penting yang memengaruhi jaringan komunikasi interpersonal sebagaimana penelitian yang dilakukan oleh Saleh (2006), Ellyta (2006), Mislini (2007), Rangkuti (2007), Damiryurek (2007) dan Ramirez (2013).

Berikutnya, selain sebagai variabel terpengaruh, jaringan komunikasi interpersonal juga dapat dijadikan sebagai variabel pengaruh yang memengaruhi variabel lainnya seperti perilaku komunikasi (Saleh, 2006), pemasaran (Ellyta, 2006), dinamika kelompok (Mislini, 2007). Hal lain yang paling banyak dilakukan antara lain menghubungkan peranan jaringan komunikasi terhadap difusi inovasi, seperti yang telah dilakukan oleh Rangkuti (2007) dan Cindoswari (2012).

Lebih lanjut, indikator yang digunakan dalam menganalisis jaringan komunikasi interpersonal yang selama ini banyak dilakukan oleh peneliti terfokus pada derajat sentralitas, seperti yang telah dilakukan oleh Cindoswari (2012) dan Bulkis (2012).

Mitchell sebagaimana dikutip oleh Scott (2009) mengemukakan bahwa melalui analisis jaringan interpersonal dapat menggambarkan kualitas hubungan antar individu yang saling berinteraksi dalam suatu sistem ataupun dalam kelompok/klik. Adapun tiga indikator utama yang dapat digunakan untuk mengukur jaringan interpersonal antara lain: (1) tingkat resiprositas (reciprocity), (2) intensitas komunikasi, dan (3) durasi. Lebih lanjut, Prell (2012) menguraikan sejumlah indikator lain yang dapat digunakan dalam menganalisis jaringan komunikasi pada tingkat individu, antara lain: (1) derajat sentralitas (degree centrality), (2) tingkat kedekatan (closeness) dan (3) tingkat kebersamaan (betweeness).

\section{DAFTAR PUSTAKA}

Agustina A. 2007. Jaringan Komunikasi dan Peran Perempuan dalam Mempertahankan Budaya Rudat Bogor (ID): Institut Pertanian Bogor.

Bulkis. 2013. Jaringan Komunikasi dan Perilaku Berusahatani Petani Tanaman Sayuran [Tesis]. Bogor (ID): Institut Pertanian Bogor.

Cindoswari AR. 2012. Jaringan Komunikasi dalam Penerapan Teknologi Produksi Ubi Kayu [Tesis]. Bogor (ID): Institut Pertanian Bogor. 
Demiryurek K. 2010. Analysis of information systems and communication networks for organic and conventional hazelnut producers in the Samsun province of Turkey. Agricultural Systems 103(7):444-452. doi: 10.1016/j.agsy.2010.04.002.

Ellyta. 2006. Analisis Jaringan Komunikasi Petani dalam Pemasaran Lidah Buaya [Tesis]. Bogor (ID): Institut Pertanian Bogor.

Hoppe B, Reinelt C. 2010. Social network analysis and the evaluation of leadership networks. The Leadership Quarterly 21(4):600-619. doi: 10.1016/j.leaqua.2010.06.004.

Mislini L. 2007. Analisis Jaringan Komunikasi pada Kelompok Swadaya Masyarakat [Tesis]. Bogor (ID): Institut Pertanian Bogor.

Mudiarta KG. 2009. Jaringan Sosial (Networks) dalam Pengembangan Sistem dan Usaha Agribisnis: Perspektif Teori dan Dinamika Studi Kapital Sosial. Forum Penelitian Agro Ekonomi 27(1):1-12. doi:

Prell C. 2012. Social Network Analysis: History, Theory \& Metodology. Singapore: SAGE.

Ramirez A. 2013. The Influence of Social Networks on Agricultural Technology Adoption. Procedia - Social and Behavioral Sciences 79:101-116. doi: 10.1016/j.sbspro.2013.05.059.

Ramirez S, Dwivedi P, Ghilardi A, Bailis R. 2014. Diffusion of non-traditional cookstoves across western Honduras: A social network analysis. Energy Policy 66:379-389. doi: 10.1016/j.enpol.2013.11.008.

Rangkuti PA. 2007. Jaringan Komunikasi Petani dalam Adopsi Inovasi Teknologi Pertanian [Tesis]. Bogor (ID): Institut Pertanian Bogor.

Rogers EM, Kincaid DL. 1981. Communication networks: toward a new paradigm for research: Free Pr.

Saleh A. 2006. Tingkat Penggunaan Media Massa dan Peran Komunikasi Anggota Kelompok Peternak dalam Jaringan Komunikasi Penyuluhan [Disertasi]. Bogor (ID): Institut Pertanian Bogor.

Scott J, Tallia A, Crosson JC, Orzano AJ, Stroebel C, DiCicco-Bloom B, O'Malley D, Shaw E, Crabtree B. 2005. Social network analysis as an analytic tool for interaction patterns in primary care practices. Ann Fam Med 3(5):443-448. doi: 10.1370/afm.344.

Van den Berg P, Arentze T, Timmermans H. 2013. A path analysis of social networks, telecommunication and social activity-travel patterns. Transportation Research Part C: Emerging Technologies 26:256-268. doi: 10.1016/j.trc.2012.10.002.

Waldstrom C. 2001. Informal Network in Organization. Denmark (DK): The Aarhus School of Business. 
